\title{
Multi-diversity clusters of commercial activities in the city of Porto: how neighbourhood concentrations shape the municipal hierarchy
}

\author{
M. Saraiva, T. Sá Marques, D. Ribeiro, P. Ribeiro (a) \\ (a) Faculty of Arts of the University of Porto, CEGOT Research Centre, Via Panorâmica s/n, 4150 - 564 Porto, miguelmsaraiva@gmail.com; tere- \\ sasamarques@gmail.com; mrcotgeo@gmail.com; paularibeiro82@gmail.com
}

Resumen

Today, commerce is regarded as city-shaping activity that has intrinsic connections with the way urban spaces are composed and function, and the choices people make on where to live and how to travel. Hence the literature is concerned about the territorial reflection of commercial hierarchies, particularly as the sector is increasingly changing due to new types of products, stores and purchase and payment options. In this paper we built on previous research associating retail with geo-morphological patterns, by analysing the hierarchies within the city of Porto, in Portugal, and focusing on neighbourhood clusters where all the five categories of retail considered are present (Daily; Occasional; Exceptional (Comparison); Occasional (Comparison); Isolated purchase). By introducing variables related to geographical proximity, morphology (relation to street segments) and the establishments themselves (activity type, opening date) we dig deeper into the organizational aspects of the commercial network, so that in future works causality effects can be understood, leading to a better managment of urban retail in a perspective of cohesion and equitable access.

Keywords: Commerce; neighbourhood scale; economic geography networks; regeneration; urban morphology

\section{INTRODUCTION - THE CHANGING FACET OF COMMERCIAL ACTIVITIES}

The UN's 2030 Agenda for Sustainable Development (UN, 2015) identifies 17 major goals and 169 targets that balance the economic, social and environmental facets of development in order to shift the course of the world towards a more sustainable and resilient path. Although the document has no mention of the word "commerce", only mentions of the word "retail" once, and in Goal 17 the use of the word "trade" relates to world markets and not day-to-day shopping, it is implicit that the equitable and sustainable development of economic activities, of which retail in all its forms is an important part of, is at the core of this policy. Goal 8 relates to the promotion of sustained, inclusive and sustainable economic growth; Goal 11 to making cities inclusive, safer, resilient and sustainable; and Goal 12 to ensuring sustainable consumption and production patterns.

Urban spaces, by the natural agglomeration of people they promote (either residents, workers or visitors), are characterized by large and diversified demand, which is met by a large and diversified offer of functions. The "city" becomes the provider of economic growth and development (Beaverstock, Faulconbridge, \& Hoyler, 2011; Marques, 2004; Mendes, 2011), allowing access to services, infrastructures, human and financial capital, suppliers and other relevant externalities (Boschma, 2010), whilst concentrating an increasing portion of socio-economic activities which gain and strive with density and proximity. These, in turn, attract new economic activities, needed to serve the existing concentrations of people and business (Nijkamp \& Kourtit, 2013).

The city is also more and more an intricate network of lifestyles, ways of life and modes of expression, that range from different forms of sociability, access to culture and leisure, and diversified structures of consumption. In this respect, many economic activities, commerce included, have changed in order to fulfill new societal needs (Reimers \& Clulow, 2004). The consumer has become the consumactor (Cachinho, 2006, 2014) as he no longer shops out of necessity or at the closest store (Rabbanee, Ramaseshan, Wu, \& Vinden, 2012). Shopping is one of the many experiences of the modern glocal metropolis, conditioned by socio-economic and urban changes (P. M. Hart \& Dale, 2014; Vaughan \& Valerie, 2009) and by the specificities of different retail environments (C. Hart, Farrell, Stachow, Reed, \& Cadogan, 2007; Pecoraro \& Uusitalo, 2014; Pine \& Gilmore, 1999).

Indeed, the notion that the distribution of retail was a mere consequence of urbanization and population density has been overcome in the past decades. Commerce can be a city-maker. It can influence market prices of 
surrounding residential areas (Haugen, 2011), and can be a determining factor in the choices of where to live and of how to travel on a daily basis (Christian et al., 2011; Manaugh \& Kreider, 2013; McConville, Rodríguez, Clifton, Cho, \& Fleischhacker, 2011). In the extreme it can drive, and even anticipate, urban development (Beyard, 2009).

Consequently, recent research has strived to understand what Saraiva (2013) termed the "morphological sense of commerce"; i.e. the influence of retail activity in the form and function of urban spaces. Although this is still an emerging field of research (Balsas, 2001; Grant \& Perrott, 2011; Musso, 2011; Saraiva \& Pinho, 2017; Sarma, 2006; Villain, 2011) authors have shown that urban regeneration through retail oriented policies can have a very positive effect in the quality, vitality and resilience of city areas (Barata-Salgueiro \& Erkip, 2014; Brunetta \& Caldarice, 2014; Emery, 2006; Findlay \& Sparks, 2009; Lowe, 2005; Procopiuck \& Djalo, 2008), even outside the city centre (Bolton \& Vaughan, 2014) and even when facing the shock wave of the global economic crisis (Wrigley \& Dolega, 2011).

Consequently, in a post crisis context and when responding to policies for greater equality and cohesion within and between urban spaces, understanding the distribution of economic activities, their relationship with the urban spaces and the processes of attraction/complementarity should constitute main objects of research for decision support. Namely, it is important to measure to what extent the spatiality of commercial spaces at the most basic neighbourhood level and their respective levels of specialization can become an instrument for the holistic requalification of territories. This is the more relevant as the offer of commerce and services is by nature a strong element of urban centrality and vitality, both at metropolitan and regional level. For example, vacant shops have been used a proxy for evaluating the effects of the recession on urban living, wellbeing and the deterioration of the physical environment (Brázio, 2013; Burns \& Willis, 2011; EU, 2016; Katyoka \& Wyatt, 2008; Michou, 2013; Seixas, 2013; Whysall, 2011; Wrigley \& Dolega, 2011).

In this paper, we build on previous research associating retail and retail vitality to geomorphological patterns to uncover hotspots of multi-diversity at neighbourhood scale that are crucial to structure the offer and guarantee a greater access to functions. Using the city of Porto, in Portugal, as a case-study, we first make an overall commercial characterization of the city. Then, we identify clusters at local scale where the five different categories of retail considered are present. Through spatial-statistical analysis we dig deeper into the organizational aspects of the commercial network, so that in future works causality effects can be understood, leading to a better managing of urban retail in a perspective of cohesion and equitable access.

\section{METHODOLOGY}

The database for the commercial structure of the metropolitan area of Porto used in this study derived from a database for all the companies that existed on the $31^{\text {st }}$ of January 2017 , compiled by the company Informa D\&B. This database was compiled from data supplied by the Simplified Company Information (IES); the Bank of Portugal; the General Direction for the Administration and Public Employment; the National Statistics Institute (INE); the Ministry of Justice and the Ministry of Finance. Subsequently, the project team did an extensive and time consuming job of georeferencing, fine-tuning and validating the database. The resulting product is a unique database in Portugal, considered to be very accurate and complete. Social information for the study area in question was obtained through the National Statistics Institute (INE, 2018).

Data compiled refers to the identification of the companies; exact location; the classification of their activity (based on the classification of economic activities - CAE); the date of inception; the economic situation; status of the activity and number of workers. From a total of de 28 thousand establishments, over 10 thousand corresponded to activities related to commerce. This selection was based on the typologies listed on the Portuguese law decree $418 / 2009$ of April the $16^{\text {th }}$, which subdivides commercial activities into eight classes: Food and drinks; Fashion; Home; Home appliances and electronics; Leisure and culture; Hygiene and personal care, Restaurants; and Services and other activities. From the complete database of economic companies in the municipality, the companies that corresponded to each of these eight categories were selected, based on their listed CAE. A total of 163 CAEs were considered, 66 concerning wholesale and the others to traditional forms of retail. A more expedite classification of activities was also devised based on the works of Sarma (2006) and Saraiva (2013; 2017), because commerce is an activity that exists in various levels of proximity and necessity. The categories created were "Daily" (including first necessity retail as coffee shops, bakers, butchers, newsstands); "Occasional" (like bookstores, music shops, toy shops, or specialized restaurants); "Exceptional (Comparison)" (that tend to cluster like shops for home products, appliances or car related); "Occasional (Comparison)" (that combine the previous 
two like fashion shops or travel agencies); "Isolated purchase" (that correspond to very rare purchases in a month like cultural or leisure activities, and that generate their own attraction and hence can be located outside central areas).

The analyses were performed at three different scales: point, street and neighborhood (statistical subsections according to INE). For the cartographic representations of the spatial distribution of activities the Kernel density method using ArcGIS software was applied. Both scalar models with a distribution of densities (with a 10 meter cell size) and more simplified conceptual models to display hotspots (with a 20 meter cell size) were computed. Furthermore, a Multiple Correspondence Analysis (MCA) method was applied to generate spatial summaries of the information and identify homogenous groups.

\section{PRESENTATION OF THE CASE STUDY}

Porto is the second largest city in Portugal. Porto's metropolitan area has about 1,7 million inhabitants (almost $20 \%$ of Portugal's), of which around 240 thousand reside in the city of Porto itself.

Today one of the most popular and successful touristic destinations in Europe, Porto witnessed a very famous recovery process since the 1990s. At that time it was characterized, particularly in the downtown area, by ageing population, a shrinking number of inhabitants, and a considerable slice of derelict buildings. During the crisis years, the municipality also witnessed a large decline in the investment to companies, a relatively small rate of survival of companies, a decline in the number of employees and GVA, and a slight decline in exports from 2013 to 2015 (INE, 2018; PORDATA, 2018).

Although it is still losing population today (other variables are again increasing) the city has been in the past two decades the object of an extensive requalification program of buildings and public spaces, associated to the promotion of cultural activities and endogenous resources. At the same time, Porto developed and cemented its position as the central area of a large economic ecosystem in the Northwest of Portugal. Porto's metropolitan area represented, in 2015, almost $16 \%$ of the national GDP, with Porto itself accounting for $23 \%$ of the gross value added (GVA) and $22 \%$ of employees of the Metropolitan Area (INE, 2018). Today, the municipality of Porto has a powerful attraction as a provider of jobs, retail and services. According to the 2011 Census data (INE, 2018) Porto was only surpassed by Lisbon in the capacity to attract employment. For every 100 residents employed in Porto, there was twice as much employees in the city.

According to the database compiled in this research, there are 10.781 commercial establishments in the municipality, $88 \%$ of which open for business, and which employ a total of 36.967 workers (an average of 3,4 per establishment). Activities are mostly concentrated in two larger poles (Figure 1). The first is in the downtown area, and the second to the northwest, in the areas known as Boavista and Bom Sucesso, generally recognized as the city's second center. These two areas are connected by a series of commercial streets and smaller concentrations, which expand by specific channels particularly towards the North and West of the city.

About $34 \%$ of all street segments (between two intersections) contain at least one commercial establishment, with 15\% containing over 3 establishments (Figure 2). Their distribution is diversified, covering the major points of the city and forming very perceptible axes.

The daily activities are, as was to be expected, the most common, representing one third of all commerce and corresponding to over 12 thousand workers (Table 1). Occasional activities comprise 7\% of the establishments; Exceptional (comparison) 16\%; Occasional (comparison) 11\%; and Isolated purchase 4\%. The percentage of the number of workers in each category is practically the same. It should be noted that these numbers are consistent with those found by Saraiva and Pinho (2017) for four other Portuguese medium-sized cities: Aveiro, Leiria, Vila Real and Évora. This means that these values can represent the natural threshold for commercial activities within a city.

Daily establishments are also dominant in over $40 \%$ of street segments with Exceptional (comparison) dominant in $15 \%$ of segments. The pattern of daily activities follows closely the overall pattern shown in Figure 1 , whilst Exceptional (comparison) also do so but with much less density. Occasional (comparison) and Occasional categories show major poles in the two main areas of the city; the downtown and Boavista, with particular and lower density concentrations in other relevant areas. Isolated activities have only a perceptible density downtown. 


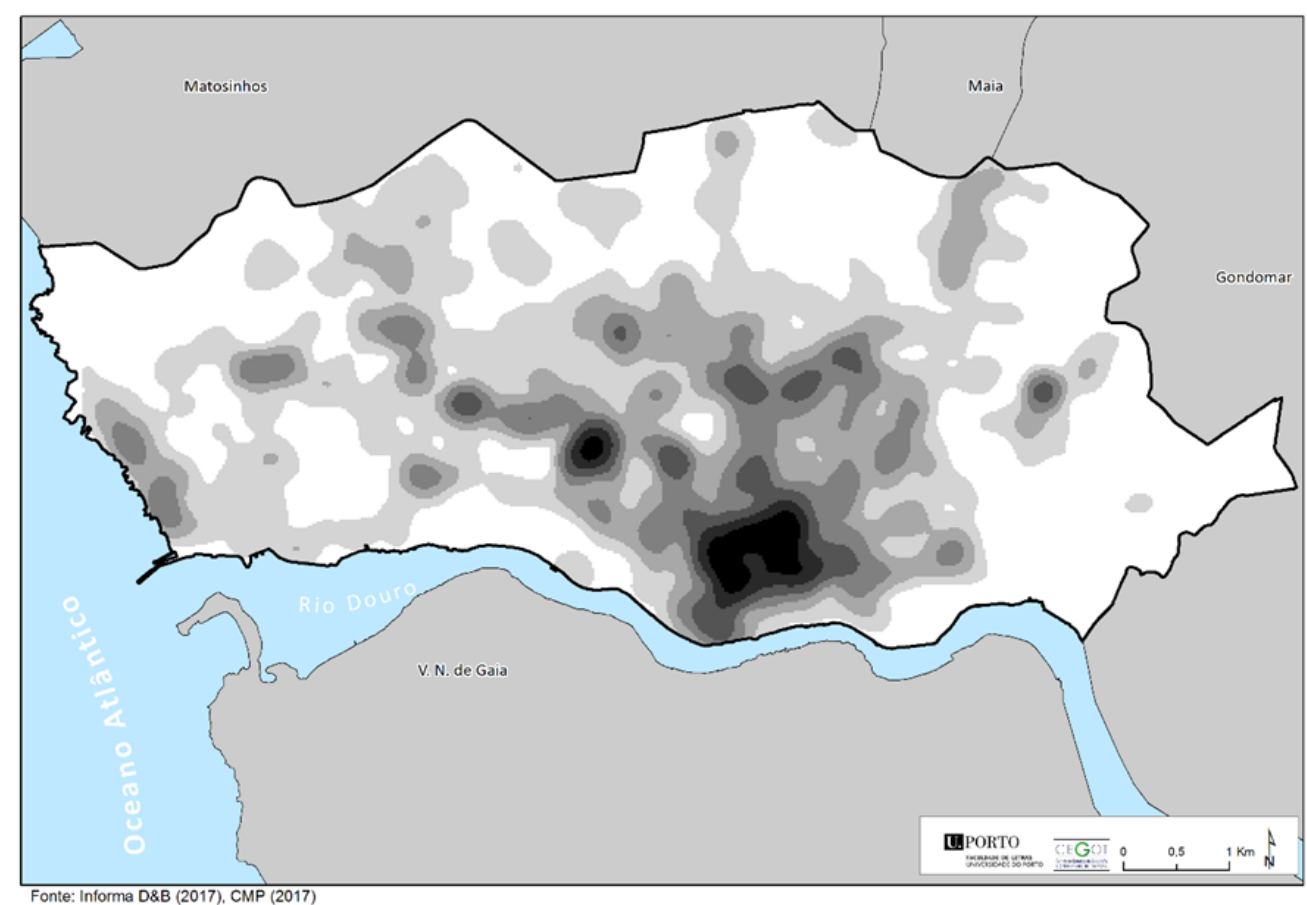

Figure 1 - Distribution model of commercial activities in the city of Porto. Source: Authors based on datasource: Informa D\&B (2017).

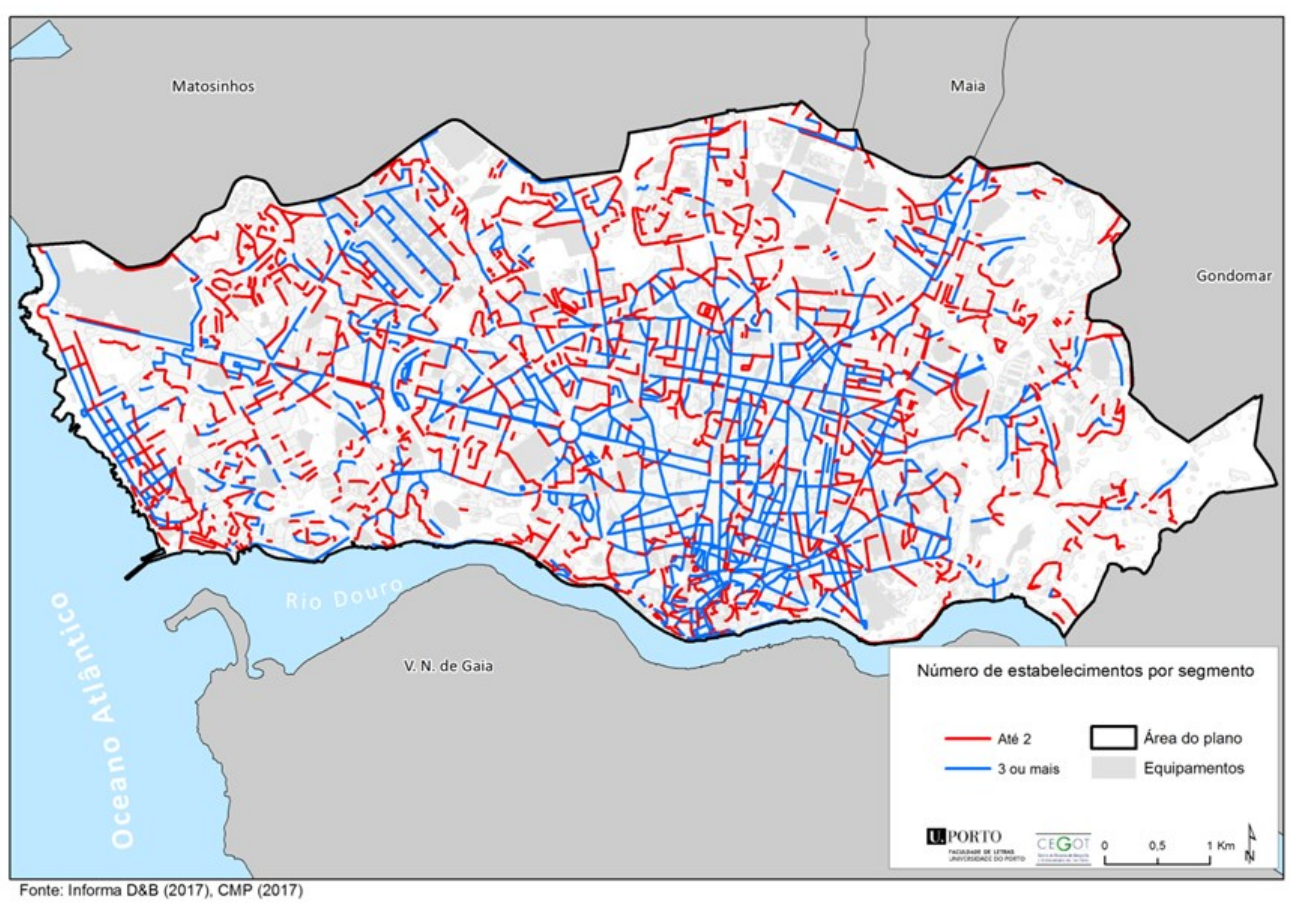

Figure 2 - Distribution of commercial activities by street segments . Source: Authors based on datasource: Informa D\&B (2017). 
Multi-diversity clusters of commercial activities in the city of Porto: how neighbourhood concentrations shape the municipal hierarchy

Table 1 - Frequency of the commercial categories in the municipality of Porto. Source: Authors based on datasource: Informa D\&B (2017).

\begin{tabular}{|c|c|c|c|c|}
\hline \multirow{2}{*}{ Category } & \multicolumn{2}{|c|}{ Establishments } & \multicolumn{2}{c|}{ Jobs } \\
\cline { 2 - 5 } & Frequency & Percentage & Frequency & Percentage \\
\hline Retail & 8265 & 76,7 & 27785 & 75,2 \\
\hline Daily (coffee shops, bakers,...) & 3566 & 33,1 & 12254 & 33,1 \\
\hline Occasional (bookstores, music shops,...) & 719 & 6,7 & 2199 & 5,9 \\
\hline Occasional (Comparison) (fashion, travel agencies,...) & 1164 & 10,8 & 4442 & 12,0 \\
\hline Exceptional (Comparison) (home products, car appliances,...) & 1757 & 16,3 & 6212 & 16,8 \\
\hline Isolated (cinema, rent-a-car,...) & 412 & 3,8 & 1270 & 3,4 \\
\hline Others (not specified) & 647 & 6,0 & 1408 & 3,8 \\
\hline Wholesale & 2516 & 23,3 & 9182 & 24,8 \\
\hline Total & 10781 & 100,0 & 36967 & 100,0 \\
\hline
\end{tabular}

\section{ANALYSIS}

The previous overall geographical analysis reveals the location of the great poles of commerce. Although it is inferred that the greatest concentrations of stores also lead necessarily to diversity in store types, this is not entirely true. Poles of commerce in residential locations, for example, although they present some density, are majorly composed of first necessity (daily) stores, irregularly complemented with Exceptional (comparison) stores like home products or, to a lesser extent, Occasional (comparison) stores like fashion.

Therefore, in this research we tried to find the most diverse locations (poles of commerce) in the city in terms of establishments to see if they coincided, or not, with the overall concentrations at city-scale. For that, an analysis was performed identifying locations at a 50, 100, 150, 200 and 250 meters where all the five categories of stores were present. The distance was measured as a buffer from each store. Stores classified as 'others', as well as wholesale establishments were at this time excluded.

Table 2 shows that at 50 meters, only around 8\% of Daily and Exceptional (comparison) stores are in the vicinity of all other categories which confirms that these are the stores types that most tend to be on their own throughout the city. The other three categories have percentages between 15-20\%. At 100 meters, it is noticeable that half of all the city's Occasional (comparison) and Isolated purchase store categories are in the vicinity of at least one store of all other types. This shows the necessity these stores have to be in denser areas. At 150 meters, the increase is about $20 \%$ in all store categories. Over half of the city's Daily and Exceptional (comparison) stores are around stores of all other types, with the numbers for the other three categories ranging from $60-70 \%$. The values become more even as the distance buffer increases. At 200 meters, between $70-80 \%$ of all store categories are in the vicinity of one another, whereas this percentage increases to between $80-90 \%$ for 250 meters, i.e. around 3 to 5 minutes walking. The remainder $10 \%$ of shops are located in peripheral areas of the city, mostly related to residential quarters, and are majorly of the Daily category (over 50\%) and of the Exceptional (comparative) category (almost 30\%). Around one third of these stores have opened for business after 2010.

Figure 3 shows the locations in the city that have all five store categories within a 50 meter radius. One

Table 2 - Percentage of the overall number of stores, by type, that have at least one store of all the other types at a given distance.

\begin{tabular}{|l|c|c|c|c|c|}
\hline \multicolumn{1}{|c|}{ Category / distance } & $50 \mathrm{~m}$ & $100 \mathrm{~m}$ & $\mathbf{1 5 0} \mathbf{m}$ & $\mathbf{2 0 0} \mathbf{m}$ & $\mathbf{2 5 0} \mathbf{m}$ \\
\hline Daily & $8,2 \%$ & $35,6 \%$ & $57,9 \%$ & $73,1 \%$ \\
\hline Occasional & $14,3 \%$ & $43,3 \%$ & $63,8 \%$ & $78,6 \%$ & $70,4 \%$ \\
\hline Exceptional (Comparison) & $7,4 \%$ & $31,1 \%$ & $54,9 \%$ & $80,3 \%$ \\
\hline Occasional (Comparison) & $16,7 \%$ & $50,2 \%$ & $72,2 \%$ & $83,8 \%$ & $80,3 \%$ \\
\hline Isolated & $19,9 \%$ & $52,0 \%$ & $68,7 \%$ & $81,8 \%$ & $89,1 \%$ \\
\hline
\end{tabular}




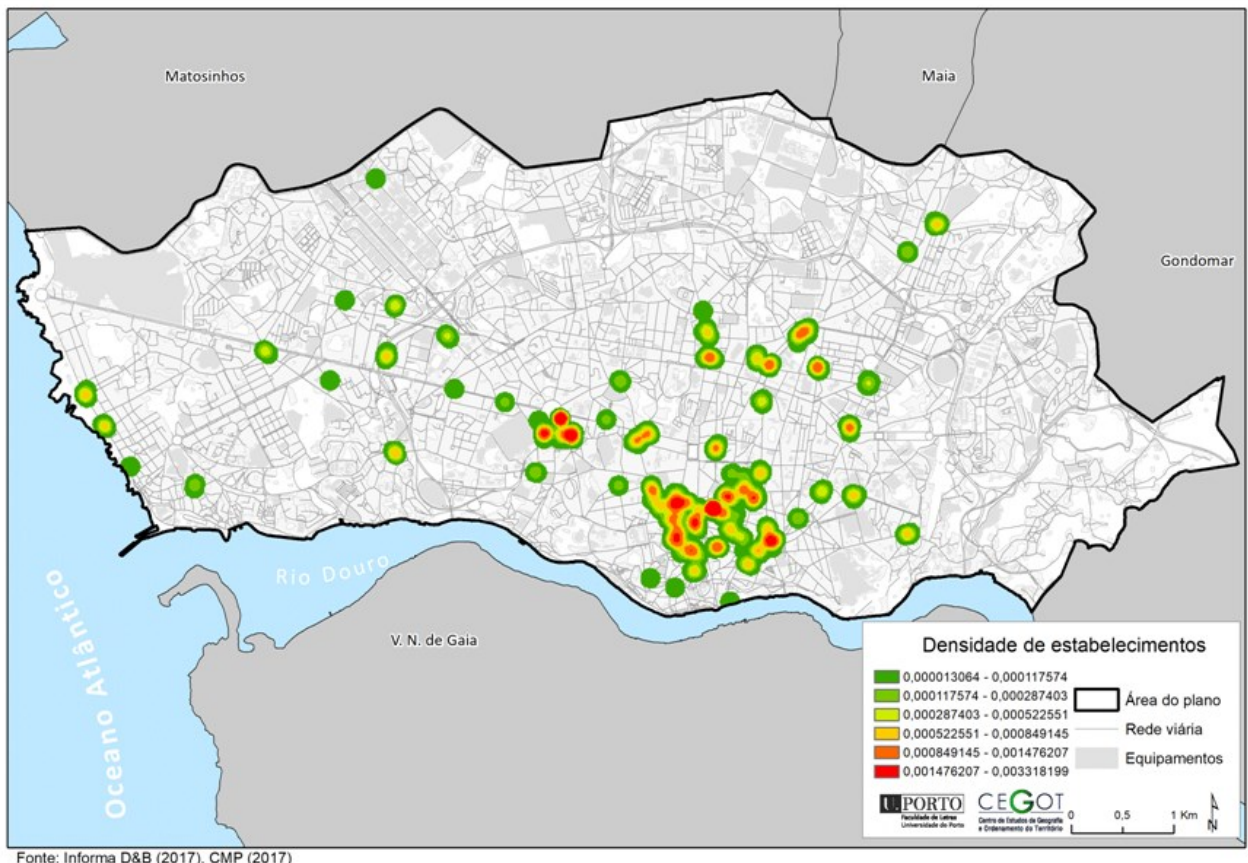

Figure 3 - Density of establishments which, in a 50 meter radius, are close to all the five categories considered. Source: Authors based on datasource: Informa D\&B (2017)

third of these stores opened for business prior to 1990, and another third after 2010. There is a slighter tendency for newer stores in the western side of the city and older stores downtown, but overall both age types co-exist in these locations.

Excluding the downtown and the Boavista concentrations, there are around 35 specific locations around the city where all five types of stores exist within a 50 meter radius. These correspond to major crossings, major residential/service areas with shopping arcades on the ground floors, relevant commercial streets (such as Cedofeita, Constituição, Fernão de Magalhães, or Costa Cabral) and other notable locations such as facing the seaside at Foz (the concentration most to the west). The eastern and northern sides of the city are majorly deprived of these poles.

Through a Multiple Correspondence Analysis (MCA) joining the commercial density by commercial types with the age of the establishments, it is possible to reach an overall classification by subsection (an administrative division more or less corresponding to a city block) (Figure 4). The city is thus divided into five typologies. A first (only $4 \%$ of subsections) represents a high intensity of commercial activity in all categories with both older and newer establishments (average 20 years). The downtown and the Boavista areas belong to this category. A second typology ( $20 \%$ of subsections) has the same variety of establishments and more or less the same average age as the first typology, but the density is clearly lower. The third typology ( $23 \%$ of subsections) has a low density of activities yet an older establishment average age (around 30 years old). The fourth typology (19\% of subsections) has a very low commercial density but a very young establishment average age (10 years, with no activities older than 20 years). These are intrinsically associated to the main and newer residential areas within the city. Finally, the last category (35\% of subsections) represents locations without stores.

But what is interesting is that only half of the stores within the 50 meter clusters are in subsections described in the first typology (intense commercial activity) (see Table 3). This means that the other half are in the other typologies, particularly the second. As the distance increases, multi-diversity clusters containing all five categories are primarily in typology 2 (always around 53\%), whereas the percentage of stores in typology 1 decreases in favor of typology 3. The main commercial areas have so much density that they naturally have a multidiversity of retail categories. But as we move from these areas to lesser dense parts of the city, the importance of such commercial concentrations increases, and as the distance buffer is augmented it is possible to reach a wider variety of stores. To be noted that there is a wider variety of concentrations of the five retail categories within typology 3 (higher store age), than in typology 4 (lower store age). This may attest to the importance of wellestablished commercial concentrations (in roundabouts or older commercial streets) in the structuring of neighborhood retail, particularly outside the downtown and central area. 


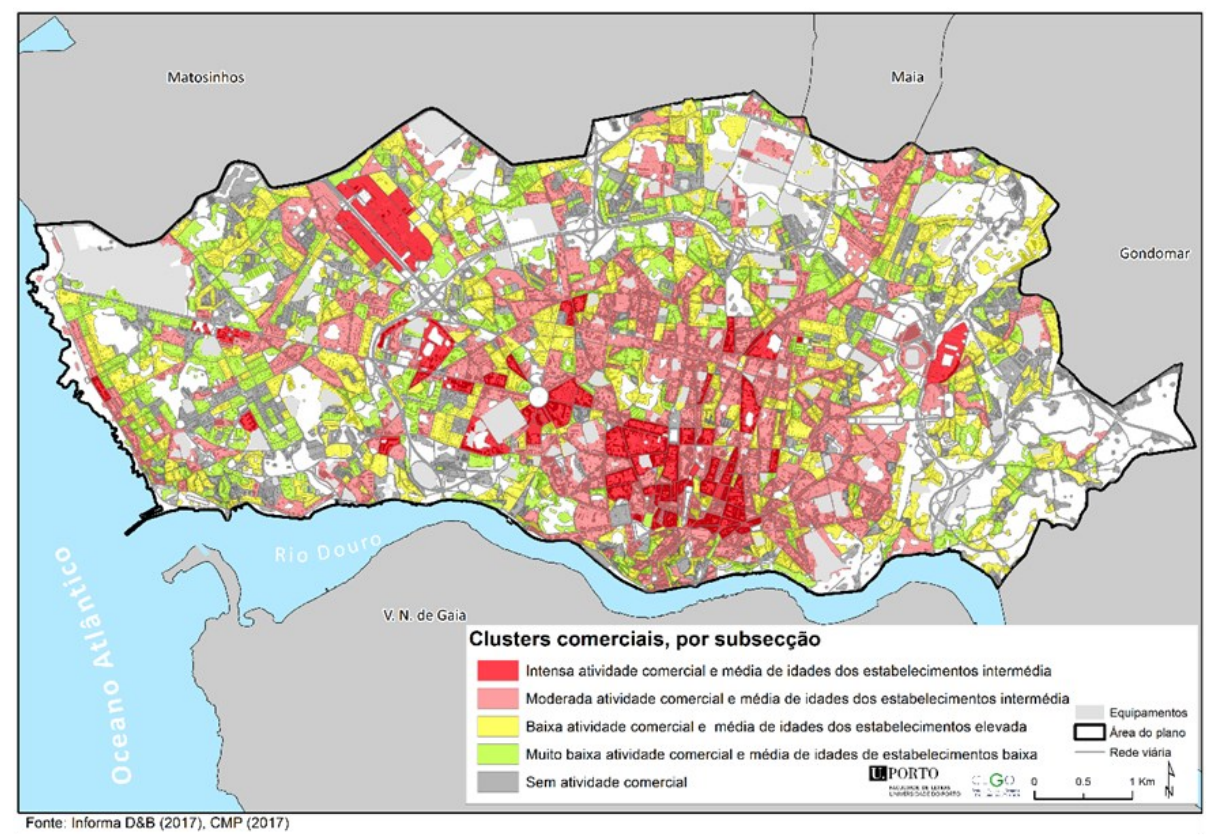

Figure 4 - Commercial clusters by subsection. Source: Authors based on datasource: Informa D\&B (2017).

Table 3 - Percentage of the overall number of stores within the multi-diversity distance clusters, by typology of subsection.

\begin{tabular}{|c|c|c|c|c|c|}
\hline & Typology 1 & Typology 2 & Typology 3 & Typology 4 & Typology 5 \\
\hline 50 meters & $50,9 \%$ & $44,6 \%$ & $3,8 \%$ & $1,8 \%$ & $0,0 \%$ \\
\hline 100 meters & $40,5 \%$ & $51,2 \%$ & $6,5 \%$ & $3,8 \%$ & $0,0 \%$ \\
\hline 150 meters & $35,1 \%$ & $52,5 \%$ & $8,7 \%$ & $4,8 \%$ & $0,0 \%$ \\
\hline 200 meters & $31,7 \%$ & $53,4 \%$ & $10,2 \%$ & $5,8 \%$ & $0,0 \%$ \\
\hline 250 meters & $30,0 \%$ & $52,5 \%$ & $11,7 \%$ & & $0,0 \%$ \\
\hline
\end{tabular}

\section{FINAL REMARKS}

The geography of shops and commercial hierarchies within a city have been extensively debated over almost the last century (see a review in Saraiva \& Pinho, 2017). However, societal, urbanistic and commercial shifts, whether the influence of technology on retail (web-purchases for example), the proliferation of multi-commercial establishments and multinational brands, the rise in tourism and power of purchase and, on the other side of the coin, the economic crisis, have all contributed to challenge these long established hierarchies. Shifts in "street commerce", particularly in city centers have never been as volatile, as the city adapts to post-modern needs and caters to new types of experiences. Yet basic necessities remain the same. Residents still need to buy bread, coffee and newspapers at the corner shop. They value living close to first necessity shops and services. Shops may be attracted to locations with more people, but people are also attracted to locations with more shops.

What this statistical and geographical analysis has shown is that Daily and Exceptional (Comparison) stores are very important to structure neighborhood commercial poles. Cities can only have (and want to have) so much large scale concentrations of commercial establishments, more than often (as in the case of Porto) associated to the downtown or to the major services and employment areas (not counting, of course, shopping malls). But moderate locations of commercial concentration, that make the transition from the central to the residential areas, can and should provide multi-functionalities. These concentrations within 50 meters, appearing in crossroads, structuring streets and near main residential areas, are natural hubs for sociability, but should also be natural hubs to guarantee the access to first necessity functions to the greater number of residents possible. They could also serve as locations for transport stops and so on. 
In this initial analyses we considered clusters containing one shop of each category, regardless of the particular activities within each category. Analyzing more specifically which activities are within these clusters is the next step, uncovering local clusters with a wider range of functions.

\section{REFERENCES}

BALSAS, C. J. L. (2001). Commerce and the European city center: Modernization, regeneration and management. European Planning Studies, 9(5), 677-682. doi:Doi 10.1080/09654310120057377

BARATA-SALGUEIRO, T., \& ERKIP, F. (2014). Retail planning and urban resilience - An introduction to the special issue. Cities, 36(0), 107-111. doi:http://dx.doi.org/10.1016/j.cities.2013.01.007

BEAVERSTOCK, J. V., FAULCONBRIDGE, J. R., \& HOYLER, M. (2011). Globalization and the City. In A. Leyshon, L. Roger, L. McDowell, \& P. Sunley (Eds.), The SAGE Handbook of Economic Geography (pp. 189-201): Sage London.

BEYARD, M. (2009). The retail bubble. Urban Land, 68(1), 30.

BOLTON, T., \& VAUGHAN, L. S. (2014). The Past, Present and Futures of the High Street: report on the Closing Conference of the Adaptable Suburbs project. Retrieved from

BOSCHMA, R. A. (2010). The aims and scope of evolutionary economic geography. In R. A. Boschma \& R. Martin (Eds.), The Handbook of Evolutionary Economic Geography: Edward Elgar, Cheltenham.

BRÁZIO, A. (2013). Vende-se. Lisboa: GHOST Editions

BRUNETTA, G., \& CALDARICE, O. (2014). Self-organisation and retail-led regeneration: A new territorial governance within the Italian context. Local Economy, 29(4-5), 334-344. doi:10.1177/0269094214535555

BURNS, E., \& WILLIS, E. (2011). Empty shops in Australian regional towns as an index of rural wellbeing. Rural Society, 21(1), 2131. doi:10.5172/rsj.2011.21.1.21

CACHINHO, H. (2006). Consumactor: da condição do indivíduo na cidade pós-moderna. Finisterra: Revista portuguesa de geografia, 41(81), 33-56.

CACHINHO, H. (2014). Consumerscapes and the resilience assessment of urban retail systems. Cities, 36(0), 131-144. doi:http://dx.doi.org/10.1016/j.cities.2012.10.005

CHRISTIAN, H., BULL, F., MIDDLETON, N., KNUIMAN, M., DIVITINI, M., HOOPER, P., \& GILES-CORTI, B. (2011). How important is the land use mix measure in understanding walking behaviour? Results from the RESIDE study. International Journal of Behavioral Nutrition and Physical Activity, 8(55). doi:10.1186/1479-5868-8-55

EMERY, J. (2006). Bullring: A case study of retail-led urban renewal and its contribution to city centre regeneration. Journal of Retail and Leisure Property, 5(2), 121-133. doi:10.1057/palgrave.rlp.5100020

EU. (2016). Urban Europe - Statistics on cities, towns and suburbs. Retrieved from Luxemburg. available at: http://ec.europa.eu/ eurostat/documents/3217494/7596823/KS-01-16-691-EN-N.pdf/0abf140c-ccc7-4a7f-b236-682effcde10f:

FINDLAY, A., \& SPARKS, L. (2009). Literature review: policies adopted to support a healthy retail sector and retail led regeneration and the impact of retail on the regeneration of town centres and local high streets. Retrieved from

GRANT, J., \& PERROTT, K. (2011). Where Is the Cafe? The Challenge of Making Retail Uses Viable in Mixed-use Suburban Developments. Urban Studies, 48(1), 177-195. doi:Doi 10.1177/0042098009360232

HART, C., FARRELL, A. M., STACHOW, G., REED, G., \& CADOGAN, J. W. (2007). Enjoyment of the Shopping Experience: Impact on Customers' Repatronage Intentions and Gender Influence. The Service Industries Journal, 27(5), 583-604. doi:10.1080/02642060701411757

HART, P. M., \& DALE, R. (2014). With or without you: The positive and negative influence of retail companions. Journal of Retailing and Consumer Services, 21(5), 780-787. doi:http://dx.doi.org/10.1016/j.jretconser.2014.06.004

HAUGEN, K. (2011). The Advantage of 'Near': Which Accessibilities Matter to Whom? European Journal of Transport and Infrastructure Research, 11(4), 368-388.

INE. (2018). Statistics Portugal. www.ine.pt/.

KATYOKA, M., \& WYATT, P. (2008). An investigation of the nature of vacant commercial and industrial property. Planning, Practice \& Research, 23(1), 125-145.

LOWE, M. (2005). The regional shopping centre in the inner city: A study of retail-led urban regeneration. Urban Studies, 42(3), 449-470. doi:Doi 10.1080/00420980500035139 
Multi-diversity clusters of commercial activities in the city of Porto: how neighbourhood concentrations shape the municipal hierarchy

MANAUGH, K., \& KREIDER, T. (2013). What is mixed use? Presenting an interaction method for measuring land use mix. The Journal of Transport and Land Use, 6(1), 63-72. doi:10.5198/jtlu.v6i1.291

MARQUES, T. (2004). Portugal na Transição do século XX/XXI: Retratos e Dinâmicas Territoriais. Afrontamento: Porto.

MCCONVILLE, M., RODRÍGUEZ, D., CLIFTON, K., CHO, G., \& FLEISCHHACKER, S. (2011). Disaggregate Land Uses and Walking. American Journal of Preventive Medicine, 40(1), 25-32.

MENDES, J. (2011). O Futuro das Cidades Coimbra: Edições Minerva.

MICHOU, M. (2013). Athens streetside arcades: silent gestures of minor occupation. Urbanistica, 1(3), 29-36.

MUSSO, F. (2011). Small Retailing, Town Centres and Inland Territories. An'Extended Town Centre Management'Perspective. Public Administration \& Regional Studies, 3rd Year(2), 6.

NIJKAMP, P., \& KOURTIT, K. (2013). The "New Urban Europe": Global Challenges and Local Responses in the Urban Century. European Planning Studies, 21(3), 291-315. doi:10.1080/09654313.2012.716243

PECORARO, M., \& UUSITALO, O. (2014). Exploring the everyday retail experience: The discourses of style and design. Journal of Consumer Behaviour, 13(6), 429-441. doi:10.1002/cb.1492

PINE, B., \& GILMORE, J. (1999). The Experience Economy: Work is Theatre and Every Business a Stage. Harvard Business School Press, Cambridge, MA.

PORDATA. (2018). Base de dados Portugal Contemporâneo. http://www.pordata.pt.

PROCOPIUCK, M., \& DJALO, A. B. (2008). Comércio como Fator de Coesão dos Centros Urbanos: caso da revitalização comercial do centro de Curitiba. Turismo-Visão e Ação, 10(3), 313-334.

RABBANEE, F. K., RAMASESHAN, B., WU, C., \& VINDEN, A. (2012). Effects of store loyalty on shopping mall loyalty. Journal of Retailing and Consumer Services, 19(3), 271-278. doi:http://dx.doi.org/10.1016/j.jretconser.2012.02.001

REIMERS, V., \& CLULOW, V. (2004). Retail concentration: a comparison of spatial convenience in shopping strips and shopping centres. Journal of Retailing and Consumer Services, 11(4), 207-221. doi:http://dx.doi.org/10.1016/S0969-6989(03)00038-9

SARAIVA, M. (2013). The morphological sense of commerce: Symbioses between commercial activity and the form and structure of Portuguese medium-sized cities. (PhD in Civil Engineering - Planning of Environment and Territory), Faculty of Engineering of the University of Porto, Porto, Portugal.

SARAIVA, M., \& PINHO, P. (2017). Spatial modelling of commercial spaces in medium-sized cities. GeoJournal, 82(3), 433-454. doi:10.1007/s10708-015-9694-7

SARMA, A. (2006). The social logic of shopping - A syntactic approach to the analysis of spatial and positional trends of community centre markets in New Delhi. (MSc Built Environment: Advanced Architectural Studies), University College London, Bartlett School of Graduate Studies.

SEIXAS, J. (2013). A cidade na encruzilhada: repensar a cidade ea sua política: Edições Afrontamento.

UN. (2015). Transforming our world: the 2030 agenda for sustainable development (RES/70/1). Retrieved from Seventieth United Nations General Assembly, New York. available at: http://www.un.org/ga/search/view_doc.asp?symbol=A/ $\mathrm{RES} / 70 / 1 \&$ Lang=E:

VAUGHAN, R., \& VALERIE, C. (2009). Retail centres: it's time to make them convenient. International Journal of Retail \& Distribution Management, 37(7), 541-562. doi:10.1108/09590550910964594

VILLAIN, J. (2011). The impact of urban form on the spatial distribution of commercial activities in Montréal. (M.SC thesis), Concordia University, Canada.

WHYSALL, P. (2011). Managing decline in inner city retail centres: From case study to conceptualization. Local Economy, 26(1), 3-17.

WRIGLEY, N., \& DOLEGA, L. (2011). Resilience, fragility, and adaptation: new evidence on the performance of UK high streets during global economic crisis and its policy implications. Environment and Planning A, 43(10), 2337-2363. 